\title{
POTENTIATION BY PHOSPHATIDYLSERINE OF CALCIUM- DEPENDENT HISTAMINE RELEASE FROM RAT MAST CELLS INDUCED BY CONCANAVALIN A
}

\author{
Katsumi SUGIYAMA, Junzo SASAKI and Hidemasa YAMASAKI \\ Department of Pharmacology, Okayama University Medical School, \\ Shikatacho, Okayama 700, Japan.
}

Accepted April 14, 1975

Concanavalin A (Con A), a lectin from jack bean, has been reported to release histamine from mast cells of hamster (1) and rat (2) and from human basophils (3). Since a wide variety of biological properties of $\mathrm{Con} A$ is concerned with its activity of binding to certain saccharide residues on the surface of cell membrane (4), histamine release by Con A from mast cells was investigated to obtain further information on the function of the cell membrane involved in the histamine release.

The present communication confirms the previous observations that Con $\mathrm{A}$ induces histamine release from rat mast cells, and further presents evidence that calcium ions are a requisite for this release and that phosphatidylserine (PS), which is known as a selective enhancer of anaphylactic histamine release from mast cells (5), also markedly enhances histamine release induced by $\mathrm{Con} \mathrm{A}$ in the presence of calcium.

Mast cells were isolated from the peritoneal fluid of male Wistar rats, weighing 300-450g, by gum arabic density gradient centrifugation (6) and suspended in a salt buffered solution (154 mM NaCl, $2.7 \mathrm{mM} \mathrm{KCl}, 0.9 \mathrm{mM} \mathrm{CaCl}_{2}, 6.7 \mathrm{mM}$ Sörensen phosphate buffer, pH 7.2, and $0.01 \%$ bovine serum albumin). $\mathrm{CaCl}_{2}$ was omitted in some of the experiments. Con A was either prepared by the method of Agrawal and Goldstein (7) or purchased from the Sigma Chemical Co., U.S.A. PS or other phospholipids (obtained from the Applied Science Lab., U.S.A.) was suspended in concentration of $1 \mathrm{mg}$ per $\mathrm{ml}$ of a $67 \mathrm{mM} \mathrm{Na}$ $\mathrm{HPO}_{4}$ solution containing $0.05 \%$ bovine serum albumin, then sonicated at $60 \mathrm{~Hz}$ for $15 \mathrm{~min}$ and diluted with the reaction medium just prior to use. PS $(0.1 \mathrm{ml})$ was added to a salt buffered solution $(0.8 \mathrm{ml})$ containing mast cells $\left(1-2 \times 10^{5}\right.$ cells), which was incubated at $37^{\circ} \mathrm{C}$ for $5 \mathrm{~min}$. Con $\mathrm{A}$ was then added to bring the total volume to $1 \mathrm{ml}$ and reaction was allowed to proceed for $10 \mathrm{~min}$ at $37^{\circ} \mathrm{C}$. After the reaction was terminated by adding $5 \mathrm{ml}$ of ice-cold salt buffered solution, the reaction mixture was centrifuged at $3,000 \mathrm{~g}$ for $20 \mathrm{~min}$. Histamine in the supernatant and precipitate was determined according to the fluorescence method of Shore et al. (8), omitting the extraction procedure because no substances were present in the supernatants or extracts which interfered with the fluorescence of histamine. The histamine release was calculated as a percentage of the total histamine content of the cells.

Con $\mathrm{A}(10-100 \mu \mathrm{g} / \mathrm{ml})$ induced the release of histamine when the medium contained $\mathrm{Ca}^{2+}$. Morphologically, degranulation of mast cells was observed. This histamine release was markedly enhanced by the addition of PS (Fig. 1), depending on the concentration of 


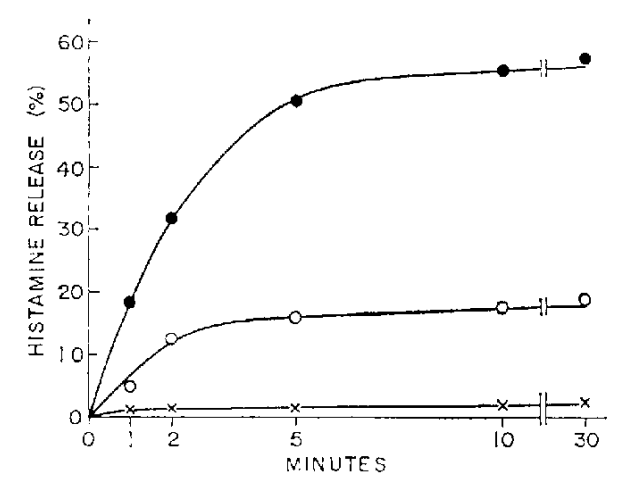

FiG. 1. Potentiation by phosphatidylserine (PS) of histamine release induced by Con A. Mast cells $\left(1-2 \times 10^{5}\right.$ colls $)$ were incubated with Con A $(10$, giml $)$ in salt buffered solution at $37 \mathrm{C}$, with or without PS $(10 / \mathrm{g} / \mathrm{ml})$, in the presence or absence of $\mathrm{CaCl}_{2}(0.9 \mathrm{mM})$. Total reaction volume was $1 \mathrm{ml}$. The reaction was allowed to proceed for $10 \mathrm{~min}$ and terminated by the addition of $5 \mathrm{ml}$ of icecold salt buffered solution. After centrifugation, histamine was assaycd in the supernatant and precipitate. Histamine release by $\mathrm{Con} A$, PS and $\mathrm{Ca}^{2+} ; \mathrm{C}$, histamine release by $\mathrm{Con} A$ with $\mathrm{Ca}^{2+} ; \times$, histamine release by $\mathrm{Con} A$ and PS without $\mathrm{Ca}^{2+}$. Each plot represents the mean from 3 experiments corrected for spontaneous release.

PS, the maximum enhancement being reached at $10 / \mathrm{g} / \mathrm{ml}$. PS was not effective in releasing histamine at concentration levels to $100 \mu \mathrm{g} / \mathrm{ml}$ in the absence of Con A. Phosphatidylethanolamine, -inositol and -choline, cardiolipin, phosphatidic acid and phosphoserine did not exhibit the enhancing activity as was observed with PS. In the absence of $\mathrm{Ca}^{2+}$, there was no histamine release by Con $\mathrm{A}$ or its enhancement by PS. Histamine release by $\mathrm{Con} \mathrm{A}$ in the presence of PS increased with the increase of $\mathrm{Ca}^{2+}$ concentration in the medium, the maximum increase reaching at $1 \mathrm{~m} \mathrm{M} \mathrm{Ca}{ }^{2+}$. For this effect $\mathrm{Ca}^{2+}$ could not be substituted with $\mathrm{Mg}^{2+}, \mathrm{Ba}^{2+}, \mathrm{Zn}^{2+}, \mathrm{Sr}^{2+}$ or $\mathrm{Mn}^{2+}$. Magnesium was rather antagonistic against calcium. Histamine release by $\mathrm{Con} \mathrm{A}$ or $\mathrm{Con} \Lambda$ with PS in $\mathrm{Ca}^{2+}$-containing medium was dependent upon temperature. The reaction reached maximum within $10 \mathrm{~min}$ at $37^{\circ} \mathrm{C}$ which was the optimum temperature (Fig. 1). At temperatures below $15^{\circ} \mathrm{C}$, the histamine release was inhibited reversibly, that is, on reincubation of the cells at $37^{\circ} \mathrm{C}$ the sensitivity to Con $\mathrm{A}$ or Con $\mathrm{A}$ with PS was normal, but when cells were treated at $45^{\circ} \mathrm{C}$ for $1 \mathrm{~min}$ the inhibition occurred irreversibly. Histamine release by $\mathrm{Con} \mathrm{A}$ showed a peak at around $\mathrm{pH} 7$ but when PS was present a plateau resulted at $\mathrm{pH}$ levels above 7.5. Histamine release induced by Con A plus PS was inhibited by either methyl- $\alpha$-glucoside, D-mannose or maltose but not by $\mathrm{D}$-galactose or lactose.

These observations suggest that binding of Con $\mathrm{A}$ to the specific carbohydrates on the mast cell surface may promote the incorporation of calcium ions into the cell membrane (or into the cytoplasm) by the aid of PS, and that this process triggers the cellular mechanism of histamine release. Keller (2) reported that histamine was released by Con A from mast cells of rats infected with Nippostrongylus brasilichsis or Syphacia muris but this release could not be observed from the mast cells of parasite-free controls. He considered that 
IgE-type rat anti-worm antibodies bind with the mast cell membrane and the bridging of Con $\mathrm{A}$ to the sugar in the $\mathrm{Fc}$ portion of these antibodies triggers the cellular enzymatic sequences. However, we observed that Con A, or Con A with PS, released histamine also from mast cells isolated from parasite-free rats, and that the release was similarly observed from the mast cells previously exposed to $\mathrm{pH} 4.0$ (unpublished observation) at which antibodies binding to the cell surface were removed (9). Therefore, the binding sites of Con $\mathrm{A}$ which are effective in initiating the process of histamine release may be glycoproteins or glycolipids of the cell membrane. Nature of the enhancement by PS of the Con A effect awaits further study.

\title{
REFERENCES
}

1) Hook, W.A., Dougherty, S.F. And Oplenheim, J.J.: Fedn Proc. 33, $1000(1973)$; 2) Keller, R.: Clin. exp. Immunol. 13, 139 (1974); 3) MAGro, A.M.: Nature 249, 572 (1974); 4) LIS, H. and Sharon, N.: A. Rev. Biochem. p. 541 (1973); 5) Goth, A. And Adams, H.R.: Science 173,1034 (1971); 6) Sugryama, K.: Japan. J. Phamocol. 21, 209 (1971); 7) Agrawal, B.B.L. and Goldstein, 1.J.: Biochim. biophys. Acta 147,262 (1967); 8) Shorl, P.A., Blrkhalter, A. and Cohn, V.H.: J. Pharmacol exp. Ther. 127, 182 (1959); 9) Ishizaka, T. And Ishizaka, K.: J. Immun. 112,1078 (1974)

\section{DIFFERENT RESPONSES TO PROSTAGLANDINS $E_{1}$ AND E $E_{2}$ OF ISOLATED CANINE CORONARY ARTERIES}

\author{
Noboru TODA, Hachiro USUI and Koichiro SAKAE \\ Department of Pharmacology, Faculty of Medicine, \\ Kyoto University, Kyoto 606, Japan
}

Accepted April 30,1970

It has been demonstrated that prostaglandin $E_{1}\left(P_{G E}\right)$ and $E_{2}$ are structurally quite similar and share the same actions on the systemic blood pressure $(1,2)$, the isolated vascular smooth muscle (3) and the sympathetic neurotransmission (4). In contrast, the present study describes the different effects of $\mathrm{PGE}_{1}$ and $\mathrm{E}_{2}$ on isolated canine coronary arteries.

Mongrel dogs were anesthetized with sodium pentobarbital and sacrificed by bleeding from carotid arteries. The interventricular branch of left coronary arteries of 0.5 to $0.8 \mathrm{~mm}$ outside diameter was isolated and helically cut into strips. The specimen was fixed under a resting tension of $1.5 \mathrm{~g}$ in a muscle bath containing the nutrient solution maintained at $37^{\circ} \mathrm{C}$. Isometric contractions and relaxations were recorded. Details of the experimental procedures are described in an earlier report (5), Paired comparison of the effect of $P G E_{1}$ and $E_{2}$ in 9 preparations from 9 dogs was made.

The addition of $\mathrm{PGE}_{1}$ in concentrations ranging from $2 \times 10^{-8}$ to $10^{-5} \mathrm{M}$ failed to produce a contraction but rather a relaxation in 2 out of 2 coronary arterics. In strips contracted with $\mathrm{PGF}_{2 \alpha}\left(5 \times 10^{-7}\right.$ to $\left.2 \times 10^{-6} \mathrm{M}\right)$, the addition of $\mathrm{PGE}_{1}$ caused a dose-related 